\title{
Post-Trasplant Lymphoproliferative Disorders (PTLD) in Adult Kidney Trasplantated Patients
}

\author{
Savina Aversa, Silvia Stragliotto, Fabio Canova, \\ Boso Caterina and Marino Dario \\ Istituto Oncologico Veneto, IRCC, Padova, \\ Italy
}

\section{Introduction}

Post-transplant lymphoproliferative disorder is a clearly recognized and potentially life threatening complication after solid organ or bone marrow transplantation. It comprises a spectrum of diseases ranging from infectious mononucleosis and lymphoid hyperplasia to highly aggressive lymphoma.

PTLD is a relatively common malignancy after transplantation with a reported incidence ranging from $2 \%$ to $10 \%$. It's the most common form of post-transplant malignancy after skin cancer with an overall mortality often exceeding 50\% (Purtilo et al., 1980; Leblond et al., 1995). Most cases of PTLD are associated with Epstein Barr virus (EBV) that leads to uncontrolled B cell proliferation in patients with a decreased function of EBV specific $\mathrm{T}$ cell because of immunosuppressive drugs. PTLD is not exclusively associated with EBV infection as EBV-negative PTLD, often developing late after transplantation.

Post transplant lymphomas differ from lymphomas in general population in histopathological findings, increased extranodal involvement, a more aggressive clinical course and poorer response to conventional treatment.

Registry-based reports however usually do not provide details of treatment and outcome: the existing single institution studies are largely reports and only a few studies include a significant number of patients with PTLD. Treatment of PTLD consists always in reduction of immunosuppression as first step. The role of chemotherapy remains unclear. In the past it was reserved for patients in whom other treatment options have failed even if the increased toxicities from cytotoxic agent, the high susceptibility to life-threatening infections. Actually most authors consider new anti CD20 mAB essential for treatment or as single agent or in association with CT but there is not a definitive agreement about schedules, duration of treatment and setting of patients.

\section{Epidemiology}

The incidence of PTLD varies according to organ transplanted, the nature of the immunosuppressive regimen and the presence or absence of EBV infection before transplantation and the age of patients. In adults PTLD has been reported to occur in $1-2,3 \%$ of kidney transplants, $1-2,8 \%$ of liver transplants, $1-6,3 \%$ of heart transplants, $2,4-5,8 \%$ of hearthlung transplants, $4,2-10$ of lung transplants and up to $10 \%$ of small bowel transplants (Table 1 ). 


\begin{tabular}{cc}
\hline Transplanted Organ & Incidence of PTLD \\
\hline Kidney & $1-2,3 \%$ \\
Liver & $1-2,8 \%$ \\
Heart & $1-6,3 \%$ \\
Lung & $4,2-10 \%$ \\
Heart/Lung & $2,4-5,8 \%$ \\
Bowel & $10 \%$ \\
\hline
\end{tabular}

Table 1. Incidence of PTLD according to transplanted organ

The incidence is significantly higher in paediatric recipients and has been reported in 1, 2$10 \%$ of kidney transplants, $4-15 \%$ of liver transplants and 6, 4-19,5 of hearth, lung and hearth and lung transplants. The higher incidence of PTLD in paediatric transplant recipient is attributable in large part to the development of primary EBV infection after transplantation. However the true incidence of PTLD in adult and paediatric recipients is difficult to determine with accuracy (Dror et a., 1999; Libertiny et al., 2001; Opelz et al., 1993) PTLD is surprisingly uncommon $(<1 \%)$ in the setting of allogenic bone marrow transplantation in the absence of specific T-cell manipulation such as use of a monoclonal anti CD3 antibody or $\mathrm{T}$ cell depletion of donor marrow. Although PTLD may occur at any time after transplantation, the risk of developing PTLD is greatest within the first year and declines over time thereafter. A report by the Transplant Collaborative Study showed the incidence of PTLD to be 224/100000 in the first year, 54/100000 in the second year and 31/100000 in the sixth year following transplantation (Bastard et al., 1994; Lo Coco et al., 1994; Cesarman et al., 1998; Opelz et al., 2003)

\section{Pathogenesis}

PTLD is often associated with clinical or serological reactivation of Epstein Barr virus infection. Tumour tissues often contain EBV-DNA sequences and express viral protein (Purtilo et al., 1980; Young et al., 1989; Hanto et al., 1981). In normal individuals, host defence mechanism make EBV infection a self limited disease and B cell proliferation is controlled by specific $\mathrm{T}$ cell lymphocytes. The infection is however not eradicated but persists in clinical latent form. In transplanted patients, partial suppression of T lymphocyte to prevent graft rejection, makes EBV-driven B cell proliferation uncontrolled and predispose to development of PTLD. EBV seronegative patients had a 10-76 times greater incidence of PTLD than EBV seropositive recipients (Walker et al., 1995). Active viral replication in immunosuppressed patients results in the expression of EBV encoded genes including oncogenes as LMP1, a gene that inhibits apoptosis by up regulating the antiapoptotic gene BCL-2 (Kulwichit et al., 1998). Others alterations are involved in some PTLD, including the accumulation of cellular genetic alteration of p53, N-ras and c-myc rearrangements. BCL-6, that encodes a transcriptional repressor gene rearranged in $35-40 \%$ of diffuse large B cell lymphoma in immunocompetent patients (Bastard et al., 1994; Lo Coco et al., 1994) presents frequent somatic mutations in PTLD representing probably a consistent step in the progression from a PTLD that can be controlled by a reconstituted immune system to one that will require more aggressive therapeutic intervention (Ceserman et al., 1998). Additional stimuli are required to promote the development of PTLD and, although these are not clearly defined, the local cytokine environment and chronic stimulation of $\mathrm{B}$ cell by alloantigen are thought to be important. 


\section{Risk factors}

The most important risk factor for PTLD development is the intensity of immunosuppression. Induction and rejection treatment with anti-T cell antibodies, especially OKT3 and ATG may lead to an increased risk of PTLD, as demonstrated by the higher incidence of early PTLD in hearth and hearth/lung recipient. With longer follow-up, is now evident that antibody prophylaxis increased the risk of lymphoma primarily during the first post-transplant year, whereas in subsequent years the risk is similar to that in non antibody-treated patients. Whether IL-2 receptor blocking monoclonal antibody, which was introduced in the late 1990s, also increases the risk of lymphoma is of great interest. Analysis of the critical 12-months data showed that use of anti IL-2 receptor antibodies was not associated with an increased risk of lymphoma (Gao et al., 2004) (Figure 1). There is no conclusive evidence that development of PTLD is associated with a single immunosuppressive agent (Gao et al., 2003; Pirsch et al., 1997; Weisner et al., 1998; Younes et al., 2000). Also the effect of everolimus and sirolimus on PTLD development is not clear. These drugs may theoretically be associated with a lower risk as demonstrated in animal model but the lack of prospective randomized trial assessing these differences restrains any firm conclusion (Yakupoglu et al., 2006; Majewski et al., 2003; Kusuki et al., 2009). A special category of patient at risk (10 to 50 fold increased risk) are EBV seronegative patients receiving allograft from EBV seropositive donors, leading to primary EBV infection (Walker et al., 1995). This is also the reason for the higher incidence of early PTLD observed in paediatric transplant recipients who often are still EBV seronegative at the time of transplantation.

A high incidence of EBV related lymphoproliferative disorders has been reported in a number of congenital immunodeficiency syndromes including severe combined immunodeficiency (SCID), ataxia teleangiectasia and Wischott Aldrich syndrome (Waldmann et al., 1983). Acquired immunodeficiency due to HIV disease has become a major clinical problem in many parts of the world. An increased incidence of aggressive non Hodgkin lymphoma which shares many of the unusual characteristics of PTLD is a manifestation of AIDS. The introduction of HAART has dramatically reduced the incidence of this life threatening manifestation of HIV.

Finally, the underlying indication for transplantation may also influence the risk for PTLD. For example hepatitis C infection (Burra et al., 2006) is associated with a particularly high risk of PTLD.

\section{Pathologic features}

A standardized approach to the classification of PTLD is important to allow consistency of reporting and to enable comparison of different treatments. Histology is essential also in differentiation between rejection and PTLD involvement of the graft. The classification of PTLD currently used is based on the histopathological appearance of the tumour. PTLD can be divided into three distinct morphological groups, as reported by the World Health Organization classification of neoplastic disease of the haematopoietic and lymphoid tissues (Table 2).

The first group comprises diffuse B cell hyperplasia, characterized by differentiated plasma cell and preservation of the normal lymphoid architecture. This type of PTLD is most often seen in children and young adults, usually occurs within the first year following transplantation and responds well to reduction in immunosuppression (Kahan et al., 2000). 
The second group comprises polymorphic PTLD characterised by nuclear atypia, tumour necrosis and destruction of underlying lymphoid architecture. Lesions in this group are highly polymorphic, usually monoclonal and include plasmacytes and blast form. Polymorphic PTLD is the most common type of PTLD in both children and adults and may occur at any time after transplantation.

The third group comprises monomorphic PTLD and includes high grade invasive lymphoma of B or T lymphocytes. This type of PTLD is often seen several years after transplantation and resembles non Hodgkin lymphoma. Monomorphic B cell PTLD can be further divided into diffuse large cell lymphoma and Burkitt or Burkitt like lymphoma. PTLD may also present with discordant lesions, in which different histological subtypes can be present in a single patient.

Although the association between EBV and PTLD is well established, the presence of EBV in tumour cell is not required for the diagnosis. So, according to the international classification, any lymphoma arising in the post-transplant patient is considered to be a PTLD.

\begin{tabular}{ll}
\hline Category & Characteristics \\
\hline Early lesion & Polyclonal \\
& Reactive plasmacytic hyperplasia and \\
& infectious mononucleosis like presentation \\
& Partial architectural preservation of the \\
& involved tissue \\
& Younger age \\
& Regress spontaneously or after reduction of \\
& immunosuppression \\
& B-cell maturation \\
Polymorphic & Monoclonal \\
& Variable response to immunosuppression \\
& withdrawal \\
Monomorphic & Monoclonal malignant B cell lymphoma \\
& Diffuse large B cell lymphoma \\
& Burkitt or Burkitt like lymphoma \\
& Plasma cell myeloma \\
& Plasmacytoma like lesion \\
Rarely T cell neoplasma including & peripheral T cell lymphoma \\
lymphoma like PTLD & Mostly seen in allogenic bone marrow \\
\hline
\end{tabular}

Table 2. World Health Organization Classification of Post-transplantation Lymphoproliferative Disorder Pathology

At least $90 \%$ of PTLD that occur in solid organ transplant patients arise from recipient cells (Weissmann e al., 1995) and the opposite apply in the case of bone marrow transplantation. Donor derived PTLD in organ transplant patient may have a predilection for the allograft (Strazzabosco et al., 1997). Some authors have suggested that they may have a worse and some a better prognosis than recipient organ PTLD even if further studies are needed in this area (Lones et al., 1997; Howard et al., 1992). 


\section{Clinical presentation}

The clinical presentation of PTLD is highly variable; this syndrome may occur in nodal or extranodal sites as single or multiples masses.

Most patients present with fever (seen in 50\%), lymphadenopathy (seen in 30\%) or nonspecific symptoms such as tonsillitis (particularly children) and weight loss. Around $15 \%$ of patients present as an emergency with intestinal perforation (Kahan et al., 2000) or with fulminant PTLD characterised by disseminated systemic disease that clinically resembles septic shock (Orjuela et al., 2003)

Keeping in mind that PTLD often presents at extra nodal sites (Bakker et al., 2005) (figure 2), including the allograft and digestive tract, there may be early signs and symptoms that should at least include PTLD in the differential diagnosis. This is especially true for allograft involvement of PTLD. Kidney transplant recipients with allograft involvement of PTLD often presents with renal dysfunction, hydronephrosis because of ureteral obstruction and fever. Lung transplant recipients may present with organ dysfunction. Because the GI tract is also frequently involved, GI signs and symptoms such as diarrhoea and bleeding may also lead to a diagnosis of PTLD, headache or confusion in case of CNS involvement, nasal airway obstruction in case of sinonasal PTLD involvement, or subtle orbital symptoms in case of orbital PTLD. Skin involvement is observed in approximately 5-10\% of all PTLD patients and must be differentiated by other cutaneous malignancy, given the fact that organ allograft recipients have an increased risk for the development of cutaneous malignancy such as squamous and basal cell carcinoma (Allen et al., 2001; Maecker et al., 2007; Beynet et al., 2004). Given this myriad of nonspecific clinical signs and symptoms, often masquerading PTLD as infection or adverse drug effects or reactions, or even absence of symptoms at all, methods for early detection of PTLD in transplant recipients would be extremely valuable.

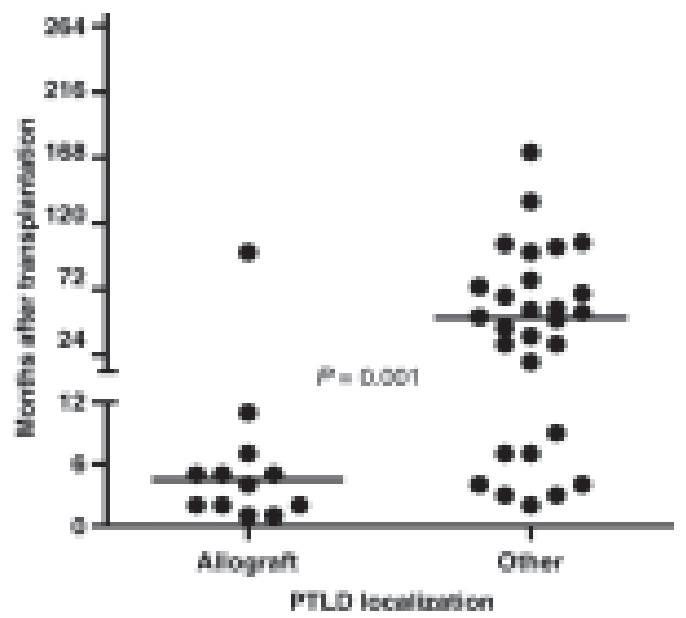

Fig. 2. Primary site of post-transplant lymphoproliferative disorder (PTLD) presentation and time after transplantation in kidney and lung transplant recipients. PTLD localized in the allograft occurred significantly earlier after transplantation when compared with PTLD localized outside the allograft (median: 4.5 months, range: 1-99 months vs. median: 51 months, range: $2-172$ months, $\mathrm{P}=0.001$ ) (adapted from ref. Bakker NA clinical transplant 2005, printed with the permission of Blackwell Publishing). 


\section{Diagnosis of PTLD}

The diagnosis of PTLD should be based on histological examination of biopsy tissue. Excision biopsy is preferable because PTLD may contain large areas of necrosis although needle biopsy may be acceptable when obtaining larger samples is impractical. Cytological preparation are useful, particularly in the analysis of effusion (Lechapt et al., 2001) and can provide adequate diagnostic material particularly if ancillary studies such as phenotypic, clonal and viral analysis are also performed. Tissue should be subjected to standard histology, examined for the presence of EBV by immunostaining or in-situ hybridization, cellular infiltrates characterised by relevant phenotypic markers and clonality estimated. Although it would be ideal to sample each tumour in cases of multicenter PTLD, this is seldom possible. Each tumour may represent a separate clone and the histological grade may be underestimated in multicentric cases. The surgeon run also the risk, in this case, of sampling a reactive node that may contain evidence of EBV infection, while the primary lymphomatous PTLD lies elsewhere. It is also useful consider biopsy of any lesion that respond in an atypical fashion, particularly if regression is documented in other concurrent lesion. The presence of PTLD within the graft itself may sometimes be mistaken for acute rejection and if there is diagnostic doubt, in-situ hybridisation for EBV encoded RNA, and PCR for VDJ heavy-chain rearrangements to determine clonality may be helpful. Molecular analysis of oncogenes and tumour suppressor genes will undoubtedly play an increasingly important role in predicting behaviour even if, at present, these techniques are not widely available and few genes have been analyzed

There is no separate staging system for PTLD and it is currently staged using the same system as NHL in the normal population. Staging of the disease should include CT of the abdomen and thorax and bone marrow aspiration. FDG-PET scanning is increasingly used as an important tool in the visualization of malignant lymphoma, especially for the detection of extranodal localization and post-treatment evaluation and has shown to be superior over conventional diagnostic techniques to differentiate between residual masses as a result of vital tumour or scar tissue. Bakker et al. ${ }^{45}$ (Bakker et al., 2006) reported 12 patients whit a highly avid FDG PTLD. Additional sites of extranodal localization of PTLD not visualized on CT scanning were found in $50 \%$ of all patients (figure 3 ).

Additional investigations should be performed as indicated, e.g. CT or magnetic resonance scan of the cranium and spinal cord or further gastrointestinal imaging.

\section{EBV DNA load monitoring after transplantation}

Early detection of PTLD may allow for prompt therapy and potentially decreased mortality. In addition elevation of EBV-DNA load in blood is considered to reflect aberrant EBV induced B-cell proliferation. For this reasons much effort has been put in developing methods that might identify patients at risk for developing PTLD by measuring the amount of circulating EBV-DNA in the peripheral blood.

Despite the consensus that PTLD patients have a significantly higher EBV-DNA load compared with healthy EBV-seropositive donors or non-PTLD transplant recipients, it is still unclear which threshold values are predictive for PTLD. Many different threshold values have been reported, all with different sensitivity (60-100\%) and specificity (71-100\%) (Lee et al., 2005; Rowe et al., 2001; Tsai et al., 2002). Another limitation of EBV-DNA load monitoring may be the observation that PTLD developing late after transplantation is not 


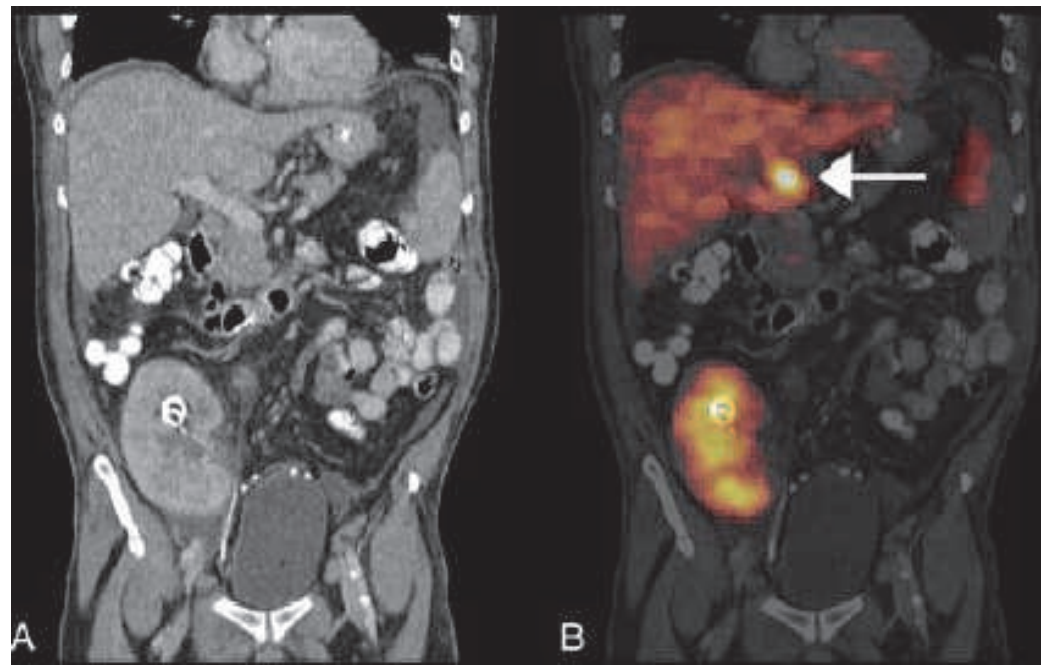

Fig. 3. Example of discordant finding. CT abdomen (A) and FDG PET fused with the same CT scan (B). Arrow indicates the histologically confirmed focal lesion with high uptake of FDG, whereas the CT scan (A) does not show any abnormalities at the site of high FDG uptake. The high uptake in the allograft, including the kidney calices and pyelum, is physiological, as is the modest uptake in liver and spleen

necessarily associated with EBV (negative staining for EBV in the tumour), and may therefore develop without a concomitant rise in EBV-DNA load. Indeed, there are studies showing EBV-negative PTLD developing late after transplantation without a rise in EBVDNA load. These observations suggest that, although increased EBV-DNA load is generally considered to represent an increase in circulating EBV-positive tumour cells, these high EBV-DNA loads in reality may represent a separate population of proliferating B-cells that may have nothing to do with development of PTLD. Instead, these proliferating B-cells may only reflect a general state of decreased T-cell surveillance in the transplant recipient In conclusion, because of the many variables that may influence the immune response of the individual transplant recipient, such as level of immunosuppression, time after transplantation, concomitant infections, type of organ transplanted, but also genetic factors, an exact cut-off value of EBV-DNA load critical for the development of PTLD in the individual patient cannot be defined. Therefore, rising EBV-DNA loads in the individual patient, instead of using a cut-off value, may be more appropriate to identify the individual patient at risk for the development of PTLD.

It has been suggested that concomitant combined monitoring of EBV-DNA load and EBVspecific cytotoxic T lymphocytes (CTL) responses (the absence of which may be used as a marker for possible overimmunosuppression) might better identify the individual patient at risk for PTLD development. The positive predictive value of high EBV-DNA loads as a predictor for PTLD development might be improved with this method. Smets et al. (Smets et al., 2002) showed that high EBV-DNA loads in patients who underwent primary EBV infection were indicative for PTLD development only if there was a low concomitant cellular immune response. 


\section{IL 10 monitoring}

Some reports have suggested that levels of IL-10 might be predictive for PTLD development (Muti et al., 2003). Although the exact relationship between IL-10 and the development of PTLD has not been fully elucidated yet, IL-10 can act as an autocrine growth factor for EBVtransformed B-cells. Although this may lead to higher local levels of IL-10, it seems doubtful that this is also reflected by a higher total IL-10 load in the peripheral blood of the transplant recipient. Given the small number of studies so far and the lack of evidence regarding the exact relation between IL-10 and the development of PTLD, the relevance for identification of the patient at risk for PTLD development is not clear.

\section{Clinical management}

The treatment of PTLD poses a major therapeutic challenge and, although there is reasonable agreement about the overall principles of treatment no controlled studies have been undertaken and most of the recommendations result from small cohorts at single institutions.

Even if no uniform approaches to the treatment have emerged, general principles are largely shared.

- Treatment must be individualised according to clinical situation and the type of organ transplanted

- Unlike non-Hodgkin lymphoma in immunocompetent patients, PTLD can be eradicated by surgical resection

- Reduction of immunosuppression is considered the first line treatment

- Antiviral agents have showed to induce regression of disease in some cases

- Chemotherapy, traditionally considered a last resort treatment, is associated with high response rate and long progression free survival

- Rituximab has emerged as treatment of choice especially in early PTLD after failure in reduce/withdrawal immunosuppression

- Radiotherapy may be appropriate for treatment of localized PTLD together with reduction in immunosuppression

\subsection{Reduction of immunosuppression}

Reduction of immunosuppression is the initial treatment in all patients with PTLD with the aim of increase antitumor activity. In EBV driven PTLD, this may partially restores CTL function resulting in an increase of EBV specific CTLs and elimination of virally infected lymphocytes, including those which constitute the tumour. The approach to reduce immunosuppressive drugs needs to be carefully individualised and will depend on the nature and extent of disease, the type of transplant recipient (life or no-life supporting graft) and the time from transplantation.

Steroids also are an important component of most chemotherapy regimen for PTLD and lymphoma in general.

A response to reduction in immunosuppression is usually seen within 2-4 weeks (Green et al., 1999). Reduction of immunosuppression leads to long term disease remission in $40-86 \%$ of paediatric patients and $25-63 \%$ of adults.

Features that predict response include a short interval between transplantation and PTLD and wild type BCL-6 (Ceserman et al., 1998). If PTLD develops within one year of the transplant up to $80 \%$ will respond to reducing in immunosuppression with a mortality of 
$40 \%$. In contrast, after one year the response rate falls to $10 \%$ with $80 \%$ of mortality (Armitiag et al., 1991).

\subsection{The role of Rituximab}

PTLD is usually of $B$ cell origin and the use of $m A B$ to deplete $B$ cell is a logical approach for treatment. Rituximab, a monoclonal antibody directed against CD20 antigen expressed on mature and immature B cells, results in profound and long-lasting depletion of B cell (6-8 months), together with hypogammaglobulinemia.

Rituximab is widely used in the treatment of diffuse large B cell lymphoma in immunocompetent patients with an overall survival at two years of $70 \%$ compared with $57 \%$ of patients treated with chemotherapy alone (Coiffer et al., 2002) rituximab has also recently been used in the treatment of patients with PTLD after solid organ transplantation as an adjunct to reduction of immunosuppression or chemotherapy.

The majority of the case reports describe the use of rituximab, at standard dose of $375 \mathrm{mg} / \mathrm{mq}$ once a week for four consecutive weeks, in the early onset PTLD, but it might be effective also for patients with late onset PTLD.

The patients treated with rituximab benefit from the short duration of such therapy in terms of response rate and less toxic effect. However, because of the high relapse rate observed in several studies, the combination of rituximab with cytotoxic drugs is recommended to be evaluated.

\subsection{Antiviral agents}

Because most PTLDs arise as a consequence of EBV infection, prophylactic measures should include avoiding over-immunosuppression of the recipient such as the use of antilymphocyte preparations, antiviral agents, EBV vaccination, in-vitro generated EBV specific CTL lines and avoiding, in EBV seronegative recipients, transplantation with an organ from an EBV positive donor.

Regression has been described following high dose acyclovir (Hanto et al., 1982; Morrison et al., 1994). Targeting EBV by antiviral agents has been attempted also for prophylaxis of PTLD. However, the latent EBV infected cells which carries EBV genome and express a limited number of viral proteins are not eliminated by the use of antiviral agents.

A potential approach for reducing the high risk of PTLD in EBV seronegative paediatric patients is to expose them to the EBV virus prior to transplantation to induce seroconversion and a vaccine using a viral membrane protein from EBV, gp350 (Gusy et al., 1995).

\subsection{Cytokine based therapy}

Agents that alter the cytokine environment of the tumour to favour remission, notably interferon- $\alpha$ and anti-IL-6 have been tried as adjuvant along with reduction of immunosuppression, but at present there is insufficient evidence to recommend their routine use. Interferon- $\alpha$ enhances T-lymphocyte cytotoxicity and has been used as an adjunct to chemotherapy to treat B cell malignancies in non-transplanted patients and in the maintenance of remission in such patients. Caution is needed when using interferon- $\alpha$ because of its toxicity and because it may initiate acute rejection by promoting CD8 T cell activity.

IL-6 may play a role in the development of PTLD by promoting the growth of EBV-infected B cells and increasing tumour development in EBV-immortalised cells. Serum levels of IL-6 
are raised in the majority of patients with PTLD. Anti-IL-6 mAb has been used in a phase 12 multi-centre clinical trial (Hadda et al., 2000).

\subsection{Rapamycine}

Rapamycine is increasingly used as an immunosuppressive agent for solid organ transplantation. In addition to its immunosuppressive effects, it also displays antiangiogenic and anti-tumour properties, and this make it a potentially attractive agent for patients in remission from PTLD, particularly those who develop chronic allograft rejection as a consequence of a reduction of immunosuppression. Rapamycin inhibits the growth of EBV-transformed B lymphocyte lines in-vitro by arresting the cell cycle in the G1 phase (Vaysberg et al., 2007). There are as yet no prospective studies addressing the use of rapamycin in the treatment or prevention of PTLD.

\subsection{Adoptive T cell therapy}

Adoptive $\mathrm{T}$ cell therapy using EBV-specific cytotoxic $\mathrm{T}$ lymphocytes (CTL) lines has generated considerable interest as a treatment for PTLD. Adoptive immunotherapy was initially advocated in allogenic bone marrow transplantation to control PTLD that was donor cell in origin. Donor CTL would restore immune surveillance against EBV driven proliferation and control PTLD. A potential risk was graft versus host disease due to the donor cell infusion: this risk could be reduced by selecting donor EBV-specific T cell ex vivo prior to infusion. This approach has been used with success as prophylaxis and treatment of PTLD after stem cell transplantation using CTL lines derived from the donor and specific for EBV gene products even if it is limited by the time required to generate the CTLs (weeks to months) and the expense for dedicated facilities.

After solid organ transplantation, PTLD is usually of recipient origin and recipient derived CTLs are required for effective killing of EBV infected B cells. It is possible to generate autologous EBV-specific CTLs from recipients who were EBV seropositive prior to transplantation. However, this approach is not applicable when PTLD arises in recipients who were EBV seronegative prior to transplantation.

\subsection{Chemotherapy}

Conventional cytotoxic chemotherapy which has been shown to be curative for many lymphomas in non-PTLD setting, has been viewed as a treatment of last resort due to very high morbidity and mortality rates. Chemotherapy is commonly used in the treatment of PTLD when reduction in immunosuppression fails to control the disease.

Various multi-drug regimens such as CHOP or CHOP like (cyclophosphamide, doxorubicin, vincristine and prednisone) have been used in PTLD patients (Wasson et al., 2006; Elstrom et al., 2006; Trappa et al., 2007; Taylor et al., 2006; Fohrer et al., 2006; Baudi et al., 2007; Patel et al., 2007; Aversa et al., 2008) (table 4).

In spite of the high RR up to $70 \%$, the associated toxicity is significant and includes treatment-related deaths in about $25 \%$ of patients. The high mortality of the standard chemotherapy regimens in the PTLD population might occur because of various factors including baseline pharmacologic immunosuppression, graft dysfunction, and colonization with resistant or hospital acquired infectious organisms.

Sepsis and other complication of chemotherapy have been the major problem in some centres, while others have found refractory disease to be common. Because this high 
toxicity, several studies are in progress to investigate the use of other agents, such as anti-B cell $\mathrm{mAb}$, in combination with lower dose and therefore less toxic chemotherapy regimes.

\begin{tabular}{|c|c|c|c|c|}
\hline & $\begin{array}{l}\text { Number of } \\
\text { patients who } \\
\text { received } \\
\text { chemotherapy }\end{array}$ & Chemotherapy & response & $\begin{array}{l}\text { Therapy- } \\
\text { associated } \\
\text { mortality }\end{array}$ \\
\hline $\begin{array}{l}\text { Wasson } \\
\text { et al, } \\
2006\end{array}$ & $\begin{array}{l}9 \text { kidney } \\
\text { transplant } \\
\text { retrospective }\end{array}$ & $\begin{array}{l}4 \text { CHOP +/- R } \\
1 \text { Ganciclovir } \\
2 \text { Decreased } \\
\text { immunosuppression } \\
1 \text { Decreased } \\
\text { immunosuppression + } \\
\text { Rituximab } \\
1 \text { Other chemotherapy }\end{array}$ & n.a. & None \\
\hline $\begin{array}{l}\text { Trappe } \\
\text { et al, } \\
2009\end{array}$ & $\begin{array}{l}58 \text { kidney } \\
\text { transplant } \\
\text { prospective }\end{array}$ & $\begin{array}{l}18 \text { Rituximab } \\
40 \mathrm{CHOP}+/-\mathrm{R}\end{array}$ & $40 \mathrm{CR}$ & 7 sepsis \\
\hline $\begin{array}{l}\text { Fohrer et } \\
\text { al, } 2006\end{array}$ & $\begin{array}{l}17 \text { kidney or } \\
\text { kidney/pancreas } \\
\text { transplant } \\
\text { prospective }\end{array}$ & 17 ACVBP & $\begin{array}{l}13 \text { CR + } \\
\text { PR }\end{array}$ & 1 Infections \\
\hline $\begin{array}{l}\text { Buadi et } \\
\text { al, } 2006\end{array}$ & $\begin{array}{l}14 \text { kidney or } \\
\text { kidney/pancreas } \\
\text { transplant } \\
\text { retrospective }\end{array}$ & $\begin{array}{l}3 \text { ProMACE CytaBOM } \\
1 \text { CHOP-R } \\
1 \text { BMT } \\
1 \text { Rituximab } \\
6 \text { Surgery } \\
2 \text { Decreased } \\
\text { immunosuppression }\end{array}$ & $\begin{array}{l}8 \mathrm{CR} \\
1 \mathrm{PR} \\
2 \mathrm{SD} \\
3 \mathrm{NE}\end{array}$ & \\
\hline $\begin{array}{l}\text { Aversa } \\
\text { et al, } \\
2008\end{array}$ & 8 prospective & $\begin{array}{l}7 \text { VACOP-B } \\
1 \text { STANFORD V }\end{array}$ & $\begin{array}{l}7 \mathrm{CR} \\
1 \mathrm{PR}\end{array}$ & $\begin{array}{l}2 \text { TRM due to } \\
\text { interstitial } \\
\text { pneumonia }\end{array}$ \\
\hline
\end{tabular}

CR: complete remission; PR: partial remission DFS : disease free survival; OS : overall survival; CHOP-R cyclophosphamide, doxorubicin, vincristine, prednisone, rituximab; PMitCEBO: prednisone, mitoxantrone, cyclophosphamide, etoposide, bleomycin, vincristine; ACVBP: doxorubicin, cyclophosphamide, vindesine, bleomycin, prednisone; ProMACE CytaBOM: cyclophosphamide, doxorubicin, etoposide, prednisone, bleomycin, vincristine, cytarabine, methotrexate, leucovorin; ABVD: doxorubicin, bleomycin, vinblastine, dacarbazine; BMT: etoposide and cyclophosphamide followed by high dose melphalan and autologous stem cell transplantation; VACOP-B: etoposide, doxorubicin, cyclophosphamide, vincristine, prednisone, bleomycin; TRM: treatment related mortality.

Table 4. Studies of chemotherapeutic treatment in patients with PTLD

\section{Reference}

Allen U, Hébert D, Moore D, Dror Y, Wasfy S; Canadian PTLD Survey Group-1998. EpsteinBarr virus-related post-transplant lymphoproliferative disease in solid organ 
transplant recipients, 1988-97: a Canadian multi-centre experience. Pediatr Transplant. 2001 Jun;5(3):198-203.

Armitage JM, Kormos R, Stuart RS. Post-transplantation lymphoproliferative disease in thoracic organ transplanted patients: ten years of cyclosporine based immunosuppression. J Heart Lung Transplat. 1991; 10: 877-886.

Aversa SML, Stragliotto S, Marino D, Calabrese F, Rigotti P, Marchini F, Gambino A, Feltrin G, Boso C, Canova F, Soldà C, Mazzarotto R and Burra P. Post-Transplant Lymphoproliferative Disorders (PTLD) after heart or kidney transplantation at a single centre: presentation and response to treatment. Acta Haematol. 2008; 120(1):36-46.

Bastard C, Deweindt C, Kerckaert JP, Lenormand B, Rossi A, Pezzella F, Fruchart C, Duval C, Monconduit M, Tilly H. LAZ3 rearrangements in non-Hodgkin's lymphoma: correlation with histology, immunophenotype, karyotype, and clinical outcome in 217 patients. Blood. 1994 May 1;83(9):2423-7.

Bakker NA, van Imhoff GW, Verschuuren EA, van Son WJ, Homan van der Heide JJ, Veeger NJ, Kluin PM, Kluin-Nelemans HC. Early onset post-transplant lymphoproliferative disease is associated with allograft localization. Clin Transplant. 2005 Jun;19(3):327-34.

Bakker NA, Pruim J, de Graaf W, van Son WJ, van der Jagt EJ, van Imhoff GW. PTLD visualization by FDG-PET: improved detection of extranodal localizations. Am J Transplant. 2006 Aug;6(8):1984-5.

Beynet DP, Wee SA, Horwitz SS, Kohler S, Horning S, Hoppe R, Kim YH. Clinical and pathological features of posttransplantation lymphoproliferative disorders presenting with skin involvement in 4 patients. Arch Dermatol. 2004 Sep;140(9):1140-6.

Buadi F, Heyeman MR, Gocke C, Rapaport A, Hakimian R, Bartlett S et al. Treatment and outcome of post-transplant lymphoproliferative disease: a single institution study. Am J Hematol. 2007 Mar;82(3):208-14.

Burra P, Buda A, Livi U, Rigotti P, Zanus G, Calabrese F, Caforio A, Menin C, Canova D, Farinati F, Aversa SML. Occurrence of post-transplant lymphoproliferative disorders among over thousand adult recipients: any role for Hepatitis C infection. Eur J Gastr Hepatol.2006, 18:1065-1070.

Cesarman E, Chadburn A, Liu YF, Migliazza A, Dalla Favera R, Knowles D. BCL-6 gene mutation in post-transplantation lymphoproliferative disorders predict response to therapy and clinical outcome. Blood 1998. 92: 2294-2302.

Coiffier B, Lepage E, Briere J, Herbrecht R, Tilly H, Bouabdallah R, Morel P, Van Den Neste E, Salles G, Gaulard P, Reyes F, Lederlin P, Gisselbrecht C. CHOP chemotherapy plus rituximab compared with $\mathrm{CHOP}$ alone in elderly patients with diffuse large-Bcell lymphoma. N Engl J Med. 2002 Jan 24;346(4):235-42.

Gao SZ, Chaparro SV, Perloth M, Montoya J, Miller JL, Dimiceli S, Hastie T, Oyer PE, Shoroeder J. Post-transplantation Lymphoproliferative Disease in Heart and HeartLung Trasplant Recipient: 30 year Experience at Stanford University. J Heart Transplant 2003, 22: 505-514. 
Dror Y, Greenberg M, Taylor G, Superina R, Hébert D, West L, Connolly B, Sena L, Allen U, Weitzman S. Lymphoproliferative disorders after organ transplantation in children. Transplantation. 1999 Apr 15;67(7):990-8.

Elstrom RL, Andreadis C, Aqui NA et al. Treatment of PTLD with rituximab or chemotherapy. Am J Transplant $2006 ; 6: 569-576$.

Fohrer C, Caillard S, Koumarianou A, Ellero B, Woehl-Jaegle ML, Meyer C. Long-term survival in post-transplant lymphoproliferative disorders with a dose-adjusted ACVBP regimen. Br J Haematol. 2006 Sep; 134(6):602-12.

Green M, Michaels MG, Webber SA, Rowe D, Reyes J. The management of Epstein-Barr virus associated post-transplant lymphoproliferative disorders in pediatric solidorgan transplant recipients. Pediatr Transplant. 1999 Nov;3(4):271-81.

Gu SY, Huang TM, Ruan L, Miao YH, Lu H, Chu CM, Motz M, Wolf H. First EBV vaccine trial in humans using recombinant vaccinia virus expressing the major membrane antigen. Dev Biol Stand. 1995;84:171-7.

Hanto DW, Frizzera G, Gajl-Peczalska J, Purtilo DT, Klein G, Simmons RL, Najarian JS. The Epstein-Barr virus (EBV) in the pathogenesis of posttransplant lymphoma. Transplant Proc. 1981 Mar 13: 756-60.

Locker J, Nalesnik M. Molecular genetic analysis of lymphoid tumors arising after organ transplantation. Am J Pathol 1989. 135:977.

Haddad E., Paczesny S, Leblond V. et al., Treatment of B-lymphoproliferative disorder with a monoclonal anti-interleukin- 6 antibody in 12 patients: a multicenter phase 1-2 clinical trial, Blood 2001; 97, 1590-1597.

Hanto DW, Frizzera G, Gajl-Peczalska KJ, Sakamoto K, Purtilo DT, Balfour HH Jr, Simmons RL, Najarian JS. Epstein-Barr virus-induced B-cell lymphoma after renal transplantation: acyclovir therapy and transition from polyclonal to monoclonal Bcell proliferation. N Engl J Med. 1982 Apr 15;306(15):913-8.

Howard TK, Klintmalm GB, Stone MJ, Cofer JB, Husberg BS, Goldstein RM, Gonwa TA Lymphoproliferative disorder masquerading as rejection in liver transplant recipients--an early aggressive tumor with atypical presentation. Transplantation. 1992 May;53(5):1145-7.

Kulwichit W, Edwards RH, Davenport EM, Baskar JF, Godfrey V, Raab-Traub N. Expression of the Epstein-Barr virus latent membrane protein 1 induces B cell lymphoma in transgenic mice. Proc Natl Acad Sci U S A. 1998 Sep 29;95(20):11963-8.

Leblond V, Sutton L, Dorent R, Davi F, Bitker MO, Gabarre J, Charlotte F, Ghoussoub JJ, Fourcade C, Fischer A, et al. Lymphoproliferative disorders after organ transplantation: a report of 24 cases observed in a single center. J Clin Oncol. 1995 Apr;13(4):961-8.

Lechapt-Zalcman E, Challine D, Delfau-Larue MH, Haioun C, Desvaux D, Gaulard P. Association of primary pleural effusion lymphoma of T-cell origin and human herpesvirus 8 in a human immunodeficiency virus-seronegative man. Arch Pathol Lab Med. 2001 Sep;125(9):1246-8.

Lee TC, Savoldo B, Rooney CM, Heslop HE, Gee AP, Caldwell Y, Barshes NR, Scott JD, Bristow LJ, O'Mahony CA, Goss JA. Quantitative EBV viral loads and immunosuppression alterations can decrease PTLD incidence in pediatric liver transplant recipients. Am J Transplant. 2005 Sep;5(9):2222-8. 
Libertiny G, Watson CJ, Gray DW, Welsh KI, Morris PJ. Rising incidence of post-transplant lymphoproliferative disease in kidney transplant recipients. Br J Surg. 2001 Oct;:88(10):1330-4.

Lo Coco F, Ye BH, Lista F, Corradini P, Offit K, Knowles DM, Chaganti RS, Dalla-Favera R. Rearrangements of the BCL6 gene in diffuse large cell non-Hodgkin's lymphoma. Blood. 1994 Apr 1;83(7):1757-9.

Lones MA, Lopez-Terrada D, Weiss LM, Shintaku IP, Said JW. Donor origin of posttransplant lymphoproliferative disorder localized to a liver allograft: demonstration by fluorescence in situ hybridization. Arch Pathol Lab Med. 1997 Jul;121(7):701-6.

Majewski M, Korecka M, Joergensen J, Fields L, Kossev P, Schuler W, Shaw L, Wasik MA. Immunosuppressive TOR kinase inhibitor everolimus (RAD) suppresses growth of cells derived from posttransplant lymphoproliferative disorder at allograftprotecting doses. Transplantation. 2003 May 27;75(10):1710-7.

Morrison VA, Dunn DL, Manivel JC, Gajl-Peczalska KJ, Peterson BA. Clinical characteristics of post-transplant lymphoproliferative disorders. Am J Med. 1994 Jul;97(1):14-24.

Muti G, Klersy C, Baldanti F, Granata S, Oreste P, Pezzetti L, Gatti M, Gargantini L, Caramella M, Mancini V, Gerna G, Morra E; Co-operative Study Group on PTLDs. Epstein-Barr virus (EBV) load and interleukin-10 in EBV-positive and EBV-negative post-transplant lymphoproliferative disorders. Br J Haematol. 2003 Sep;122(6):92733.

Opelz G, Henderson R. Incidence of non-Hodgkin lymphoma in kidney and heart transplant recipients. Lancet. 1993 Dec 18-25;342(8886-8887):1514-6.

Opelz G, Dohler B. Lymphoma after Solid Organ Transplantation: a collaborative Transplant Study Report. Am J Transplant 2003; 4:222-30.

Opelz G, Daniel V, Naujokat C, Fickenscher H, Dohler B. Effect of cytomegalovirus prophylaxis with immunoglobulin or with antiviral drugs on post-transplant non Hodgkin lymphoma: a multicentre retrospective analysis. Lancet Oncology 2007; 8: 212-18.

Orjuela M, Gross TG, Cheung YK, Alobeid B, Morris E, Cairo MS. A pilot study of chemoimmunotherapy (cyclophosphamide, prednisone, and rituximab) in patients with post-transplant lymphoproliferative disorder following solid organ transplantation. Clin Cancer Res. 2003 Sep 1;9(10 Pt 2):3945S-52S.

Paranjothi S, Yusen RD, Kraus MD, Lynch JP, Patterson GA, Trulock EP. Lymphoproliferative disease after lung transplantation: comparison of presentation and outcome of early and late cases. J Heart Lung Transplant. 2001 Oct;20(10):105463.

Patel H, Vogl DT, Aqui N, Shaked A, Olthoff K, Markmann J, Reddy R, Stadtmauer EA, Schuster S, Tsai DE. Posttransplant lymphoproliferative disorder in adult liver transplant recipients: a report of seventeen cases. Leuk Lymphoma. 2007 May;48(5):885-91.

Pirsch JD, Miller J, Deierhoi MH, Vincenti F, Filo RS. A comparison of tacrolimus (FK506) and cyclosporine for immunosuppression after cadaveric renal transplantation. FK506 Kidney Transplant Study Group. Transplantation. 1997 Apr 15;63(7):977-83. 
Purtilo DT. Epstein-Barr-virus-induced oncogenesis in immune-deficient individuals. Lancet. 1980 Feb 9;1(8163):300-3.

Rowe DT, Webber S, Schauer EM, Reyes J, Green M. Epstein-Barr virus load monitoring: its role in the prevention and management of post-transplant lymphoproliferative disease. Transpl Infect Dis. 2001 Jun;3(2):79-87.

Strazzabosco M, Corneo B, Iemmolo RM, Menin C, Gerunda G, Bonaldi L, Merenda R, Neri D, Poletti A, Montagna M, Del Mistro A, Faccioli AM, D'Andrea E. Epstein-Barr virus-associated post-transplant lympho-proliferative disease of donor origin in liver transplant recipients. J Hepatol. 1997 Apr;26(4):926-34.

Taylor AL, Bowles KM, Callaghan CJ, Wimperis JZ, Grant JW, Marcus RE, Bradley JA. Anthracycline-based chemotherapy as first-line treatment in adults with malignant post transplant lymphoproliferative disorder after solid organ transplantation. Transplantation. 2006 Aug 15;82(3):375-81.

Trappe R, Hinrichs C, Appel U, Babel N, Reinke P, Neumayer HH, Budde K, Dreyling M, Dührsen U, Kliem V, Schüttrumpf S, Hauser IA, Mergenthaler HG, Schlattmann P, Anagnostopoulos I, Doerken B, Riess H. Treatment of PTLD with rituximab and $\mathrm{CHOP}$ reduces the risk of renal graft impairment after reduction of immunosuppression. Am J Transplant. 2009 Oct;9(10):2331-7.

Tsai DE, Nearey M, Hardy CL, Tomaszewski JE, Kotloff RM, Grossman RA, Olthoff KM, Stadtmauer EA, Porter DL, Schuster SJ, Luger SM, Hodinka RL. Use of EBV PCR for the diagnosis and monitoring of post-transplant lymphoproliferative disorder in adult solid organ transplant patients. Am J Transplant. 2002 Nov;2(10):946-54.

Vaysberg M, Balatoni CE, Nepomuceno RR, Krams SM, Martinez OM. Rapamycin inhibits proliferation of Epstein-Barr virus-positive B-cell lymphomas through modulation of cell-cycle protein expression. Transplantation. 2007 Apr 27;83(8):1114-21.

Waldmann TA, Misiti J, Nelson DL, Kraemer KH. Ataxia-telangiectasis: a multisystem hereditary disease with immunodeficiency, impaired organ maturation, x-ray hypersensitivity, and a high incidence of neoplasia. Ann Intern Med. 1983 Sep;99(3):367-79.

Walker RC, Paya CV, Marshall WF, Strickler JG, Wiesner RH, Velosa JA, Habermann TM, Daly RC, McGregor CG. Pretransplantation seronegative Epstein-Barr virus status is the primary risk factor for posttransplantation lymphoproliferative disorder in adult heart, lung, and other solid organ transplantations. J Heart Lung Transplant. 1995 Mar-Apr;14(2):214-21.

Wasson S, Zafar MN, Best J, Reddy HK. Post-transplantation lymphoproliferative disorder in heart and kidney transplant patients: a single-centre experience. J Cardiovasc Pharmacol Ther. 2006 Mar;11(1):77-83.

Weisner RH. A long term comparison of Tacrolimus (FK 506) versus cyclosporine in liver transplantation: a report of the US FK506 Study Group. Transplantation 1998; 66:493-499.

Weissmann DJ, Ferry JA, Harris NL, Louis DN, Delmonico F, Spiro I. Posttransplantation lymphoproliferative disorders in solid organ recipients are predominantly aggressive tumors of host origin. Am J Clin Pathol. 1995 Jun;103(6):748-55.

Young L, Alfieri C, Hennessy K, Evans H, O'Hara C, Anderson KC, Ritz J, Shapiro RS, Rickinson A, Kieff E, et al. Expression of Epstein-Barr virus transformation- 
associated genes in tissues of patients with EBV lymphoproliferative disease. $\mathrm{N}$ Engl J Med. 1989 Oct 19;321(16):1080-5.

Younes BS, McDiarmid SV, Martin MG, Vargas JH, Goss JA, Busuttil RW, Ament ME. The effect of immunosuppression on posttransplant lymphoproliferative disease in pediatric liver transplant patients. Transplantation. $2000 \mathrm{Jul}$ 15;70(1):94-9. 


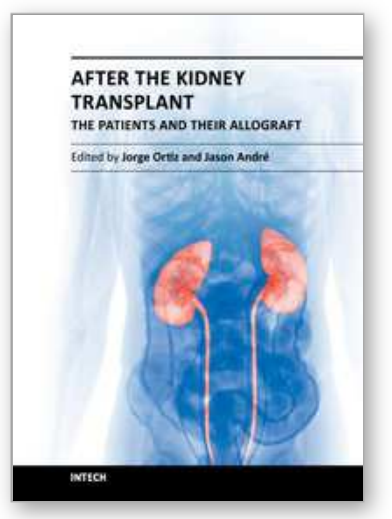

\author{
After the Kidney Transplant - The Patients and Their Allograft \\ Edited by Prof. Jorge Ortiz
}

ISBN 978-953-307-807-6

Hard cover, 386 pages

Publisher InTech

Published online 17, August, 2011

Published in print edition August, 2011

There are many obstacles in kidney transplantation. For the transplant team, there is the balance between immunosuppression to aid in the recipientâ $€^{\mathrm{TM}} \mathrm{S}$ tolerance of the allograft and the infection risk of a suppressed immune system. These potential long term complications of kidney transplantation are relatively well known, but there are many other complications that patients and families do not consider when preparing themselves for a kidney transplant. Although the benefits of attempting a kidney transplant far outweigh downfalls of the long term sequelae, kidney transplantation is by no means a benign procedure. It is the hope of these authors that the reader will leave with a sense of understanding towards the kidney recipients.

\title{
How to reference
}

In order to correctly reference this scholarly work, feel free to copy and paste the following:

Savina Aversa, Silvia Stragliotto, Fabio Canova, Boso Caterina and Marino Dario (2011). Post-Trasplant Lymphoproliferative Disorders (PTLD) in Adult Kidney Trasplantated Patients, After the Kidney Transplant The Patients and Their Allograft, Prof. Jorge Ortiz (Ed.), ISBN: 978-953-307-807-6, InTech, Available from: http://www.intechopen.com/books/after-the-kidney-transplant-the-patients-and-their-allograft/post-trasplantlymphoproliferative-disorders-ptld-in-adult-kidney-trasplantated-patients

\section{INTECH}

open science | open minds

\section{InTech Europe}

University Campus STeP Ri

Slavka Krautzeka 83/A

51000 Rijeka, Croatia

Phone: +385 (51) 770447

Fax: +385 (51) 686166

www.intechopen.com

\section{InTech China}

Unit 405, Office Block, Hotel Equatorial Shanghai

No.65, Yan An Road (West), Shanghai, 200040, China

中国上海市延安西路65号上海国际贵都大饭店办公楼405单元

Phone: +86-21-62489820

Fax: $+86-21-62489821$ 
(C) 2011 The Author(s). Licensee IntechOpen. This chapter is distributed under the terms of the Creative Commons Attribution-NonCommercialShareAlike-3.0 License, which permits use, distribution and reproduction for non-commercial purposes, provided the original is properly cited and derivative works building on this content are distributed under the same license. 